\title{
Nervus terminalis innervation of the goldfish retina and behavioral visual sensitivity
}

\author{
Roger E. Davis ${ }^{1}$, Ann Kyle ${ }^{2}$ and Paul D. Klinger ${ }^{1}$ \\ 'Mental Health Research Institute and Neuroscience Laboratory, University of Michigan, Ann Arbor, MI \\ 48109 (U.S.A.) and 'Department of Anatomy, University of Calgary, Calgary, Alta. (Canada)
}

(Received 7 March 1988: Revised version received 29 April 1988; Accepted 2 May 1988)

Key words: Classical conditioning; Goldfish; Retina; Telencephalon; Nervus terminalis; Visual behavior; Visual sensitivity

The possibility that axon terminals of the nervus terminalis in the goldfish retina regulate visual sensitivity was examined psychophysically. Fish were classically conditioned to respond in darkness to a diffuse red light conditioned stimulus. Bilateral ablation of the olfactory bulb and telencephalon had no signifcant effect on response threshold which was measured by a staircase method. Retinopetal nervus terminalis fibres thus appear to play no role in maintaining scotopic photosensitivity.

In goldfish and other teleosts, ganglion cells of the nervus terminalis $(\mathrm{Nt})$ project rostrally to the olfactory epithelium and caudally to and through the telencephalon to the retina, diencephalon, and midbrain $[5,7,11,15]$. Nt neurons that project to the retina of goldfish colocalize peptides immunologically similar to luteinizing hormone-releasing hormone ( $\mathrm{LH}-\mathrm{RH}$ ), FMRFamide, and the $\mathrm{N}$-terminal region of substance $\mathbf{P}[12,14]$ and terminate on dopaminergic interplexiform cells [17], and at least two types of amacrine cells [13], and possibly bipolar and ganglion cells [14]. Thus, the $\mathrm{Nt}$ is potentially capable of complex influences on vision.

Few studies have examined the role of the $\mathrm{Nt}$ in retinal physiology. Application of presumed $\mathrm{Nt}$ neurotransmitters/neuromodulators, LH-RH and FMRFamide, or their analogues altered ganglion cell activity in the isolated goldfish retina [16]. In this study, we tested the effect of Nt destruction on the visual sensitivity of darkadapted goldfish.

To eliminate $\mathrm{Nt}$, we bilaterally ablated the telencephalon, olfactory bulbs and proximal olfactory nerves. This operation removed the $\mathrm{Nt}$ ganglia, which are located in the olfactory nerves along the rostral surface of the bulbs, any Nt cells displaced along the medial bulb surface or olfactory tracts, and centrally projecting Nt fibers including those to the retinas. Vision was assessed with an objective psychophysical

Correspondence: R.E. Davis, Neurosciences Laboratory Building, University of Michigan, 1103 East Huron, Ann Arbor, MI 48104-1687, U.S.A. 
technique, similar to that used by others [9], that permits monocular and sequential testing in each fish [4]. The index of vision was a branchial suppression response (BSR) that was evoked by a spot of red light (the conditioned stimulus, CS) that was classically conditioned to an electric shock (unconditioned stimulus, US). Acquisition and retention of classical conditioning are not impaired in telencephalon-ablated goldfish $[6,10]$.

Goldfish (Carassius auratus L.), 8-12 g, obtained from Ozark Fisheries, Stoutland. $\mathrm{MO}$, were kept in individual home tanks at $30^{\circ} \mathrm{C}$ as previously described [2, 4]. The experiments were carried out during the months of January and February. Fish were conditioned individually in 3 glass tanks, $15 \times 15 \times 30 \mathrm{~cm}$, the water being changed at the start of each session. The fish was gently restrained in a holder. Branchial ventilation movements were detected by the thermistor method [1,9], the amplified thermistor signal being recorded on an ink-writing polygraph in a separate room. The CS was produced by turning-on a light-emitting diode (red, diffused-wide beam LED, $4 \mathrm{~mm}$ diameter; General Instrument, MV 5732) that was ca. $2.5 \mathrm{~cm}$ from the eye along the visual axis. The visual angle subtended by the LED was ca. II and the image was presumably unfocused [8]. Fish could change position with respect to the CS by moving forward or backward up to ca. $1 \mathrm{~cm}$. In the trial, the CS was turned on for $5 \mathrm{~s}$ and terminated with delivery of the US. The US was a 0.5 -s pulse from 7 to $8 \mathrm{~mA}$ (RMS) $60 \mathrm{~Hz}$ constant current that was passed between two steel clectrodes on opposite sides of the fish holder [1].

Fish were conditioned to respond to the CS, in a sequence of 3 or 4 sessions of conditioning trials, approx. 20 trials per session, over a period of $1-3$ weeks. The tanks were brightly illuminated from above by fluorescent lamps [4]. The BSR was measured by digital conversion of the analog branchiogram, using a microprocessor. We measured the branchiogram during the 5-s CS-US interval (B) and during the 5 -s interval (A) preceding the onset of the trial. The BSR was expressed as the percentage change in the length in interval $B$ relative to the length in $A, S R=[100 \times$ $(1-B / A)]$. The criterion for visual detection of the CS was a decrease in BSR of $>30 \%[2]$.

Fish screened for responding to the CS in bright illumination were administered two test sessions a week apart to measure their response threshold in darkness. The fish was kept in darkness for $2 \mathrm{~h}$ before being placed in the conditioning tank. The threshold was measured using a staircase method in which the light intensity in different trials varied from 1 to $1600 \mathrm{~cd} / \mathrm{m}^{2}$ by varying the electrical current. The LED is a convenient stimulus source as intensity is relatively linear with the current and the emission spectrum is constant (optical data provided by General Instrument). We measured luminance using an S.I.E. photometer with the light reflected off a mattewhite surface (Fig. 1). The intensity was decreased when the fish had responded in the previous trial and increased when the fish failed to respond until a stable threshold was reached. The data were reduced by estimating the LED current which resulted in a response in $50 \%$ of trials. The fish proved to be very sensitive to the CS. To produce a subthreshold CS, a translucent, white polyethylene screen, $2 \mathrm{~cm}$ $\times 2 \mathrm{~cm} \times 8 \mathrm{~mm}$ thick was placed in front of the LED. Further, the tank was illumi- 


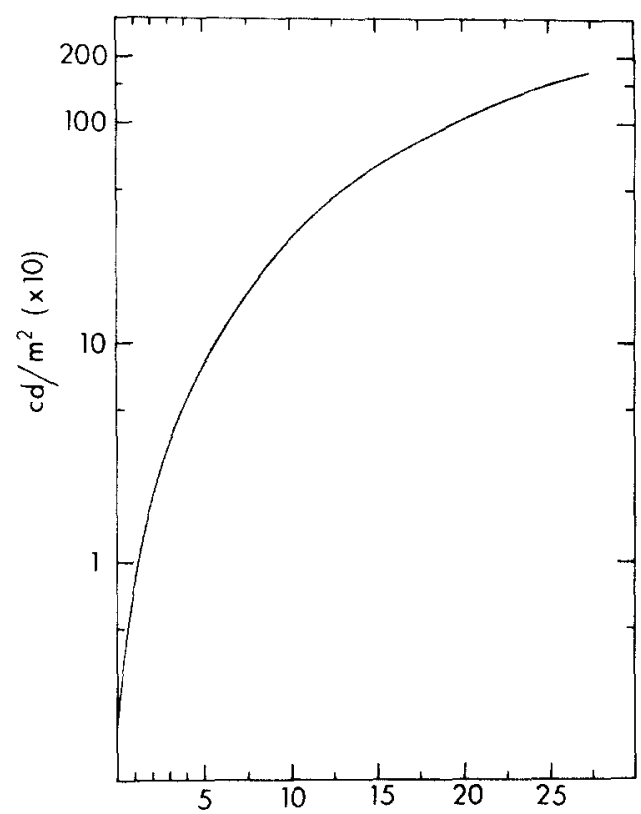

Fig. 1. Luminance of the diffuse red LED in the experimental tank vs electrical current.

nated by $0.2 \mathrm{~cd} / \mathrm{m}^{2}$ of indirect, cool white, fluorescent illumination. The adapting light was added because the lowest LED current we chose to employ $(0.14 \mathrm{~mA})$ produced a CS that was only marginally subthreshold.

After measurement of their dark-adapted thresholds, 5 fish received olfactory bulb and telencephalon ablation and 2 were administered sham operations. Anesthesia was by immersion in $0.04 \%$ trimethane methyl sulfonate (Sigma) buffered with Tris fish buffer (Sigma) to $\mathrm{pH}$ 6.5-7.5. An opening was made in the dorsal cranium by reflecting a 3-sided bone flap [3] and both bulbs, olfactory tracts, and telencephalic hemispheres were removed by aspiration. Then the flap was replaced and the fish was returned to the home tank to recover. The controls received only the craniotomy. At 1 week following the surgery, the fish received the first of a sequence of 3 weekly

TABLE J

\section{ESTIMATED 50 PERCENT RESPONSE THRESHOLD (mA)}

Mean and (S.D.). The CS intensity was not measured but the screen presumably allowed only a small amount of the diode illumination to reach the fish.

\begin{tabular}{|c|c|c|c|c|c|c|}
\hline \multirow[t]{3}{*}{ Group } & \multirow[t]{3}{*}{$n$} & \multicolumn{5}{|c|}{ Weekly test session } \\
\hline & & \multicolumn{2}{|c|}{ Preoperative } & \multicolumn{3}{|c|}{ Postoperative } \\
\hline & & $I$ & 2 & $l$ & 2 & 3 \\
\hline Ablates & 5 & $1.3(0.03)$ & $1.2(0.02)$ & $I .3(0.05)$ & $1.0(0.03)$ & $1.1(0.01)$ \\
\hline Control & $I$ & . & 1.0 & 0.9 & 1.2 & 1.4 \\
\hline
\end{tabular}


threshold test sessions. The test procedure was the same as in the preoperative sessions.

The results showed that behavioral sensitivity to the CS illumination was not altered (Table I). A one-way ANOVA on the data for the ablates revealed no significant difference between the pre- and postoperative threshold measurements $(F=0.48$, $\mathrm{df}=4,20, P>.05$ ). One control died during the experiment. The remaining control's threshold was similar to those of the ablates. Upon termination of the study, the fish were euthanized by an overdose of anesthetic to verify the brain lesions by direct observation with a dissecting microscope. The telencephalon and olfactory bulbs appeared to be normal in gross morphology in the control fish, and completely absent in the experimental fish. Varying amounts of disorganized tissue and clotted blood were present in the rostral preoptic area.

The possible visual functions of the $\mathrm{Nt}$ innervation of the retina remain unclear. We assume that the pre- and postoperative response thresholds reflected sensitivity to retinal and not extraretinal photostimulation. Extraretinal photoresponding has been demonstrated to occur in goldfish but in only a small proportion of individuals $(<5 \%)$ and the threshold of response is comparatively high [3]. If Nt fibers terminating on the interplexiform cells [17] or amacrine cells [13] affect the fish's sensitivity to retinal photostimulation, the dark-adapted threshold of a conditioned response to diffuse illumination would seem likely to be affected. Based on the negative outcome of our limited experiment, the strong inference is that retinopetal $\mathrm{Nt}$ fibers neither enhance nor inhibit scotopic photosensitivity for large unfocused stimuli.

We thank Dr. W.K. Stell for his helpful comments on this manuscript. This work was supported by the Mental Health Research Institute, University of Michigan, and the Natural Sciences and Engineering Research Council of Canada.

I Davis. R.E.. A method of restraining goldfish during conditioning of electric shock-induced suppression of breathing movements, Behav. Res. Methods Instrum., 13 (1981) 650652 .

2 Davis, R.E. and Schlumpf, B.E.. Circumvention of extraretinal photoresponses in assessing the recovery of vision in goldfish following optic nerve crush, Behav. Brain Res., 7 (1983) 6579.

3 Davis, R.E. and Schlumpi. B.E., Visual recovery in goldtish following unilateral optic tectum ablation: evidence of competition between optic axons for tectal targets, Behav. Brain Res. 13 (1984) 287291.

+ Davis, R.E., Schlumpf, B.E. and Klinger, P.D., Systemie colchicine inhibits goldfish optic nerve regeneration. Toxicol. Appl. Pharmacol., 73 (1984) 268274.

5 Iemski. L.S. and Northcutt, R.G.. The terminal nerve: a new chemosensory system in vertebrates. Science. $220(1983) 435437$.

6 Hollis. K. L. and Overmier, J.B., Effect of telencephalon ablation on the reinforcing and eliciting properties of species-specific events in Benta splendens, J. Comp. Physiol. Psychol., 96 (1982) 574590.

7 Münz. H.. Clatas, B., Stumpf, W.E. and Jennes, L., Centrifugal innervation of the retina by luteinizing hormone releasing hormone (LHRH)-immunoreactive telencephalic neurons in teleostean fishes, Cell Tissuc Res., 222 (1982) 313-323.

8 Northmore, D.P.M. and Dvorak, C.A., Contrast sensitivity and acuity of the goldfish. Vision Res., 19 (1979), 255261 .

9 Northmore. D.P.M. and Yager, D., Psychophysical methods for investigations in vision in fishes. In M.A. Ali (Ed.), Vision in Fishes, Plenum. New York, 1975. pp. 689704. 
10 Overmier, J.B. and Curnow, P.F., Classical conditioning, pseudoconditioning, and sensitization in "normal' and forebrainless goldfish, J. Comp. Physiol. Psychol., 68 (1969) 193198.

11 Springer, A.D., Centrifugal innervation of goldfish retina from ganglion cells of nervus terminalis, J Comp. Neurol., 214 (1983) 404415.

12 Stell, W.K., Chohan, K.S. and Kyle, A.L., Substance P-immunoreactivity coexists with LHRH- and FMRFamide-immunoreactivity in nervus terminalis efferents to goldfish retina, Invest. Opthalmol. Vis. Sci., Suppl. 26 (1985) 277.

13 Stell, W.K., Walker, S.E. and Ball, A.K., Functional-anatomical studies on the terminal nerve projection to the retina of bony fishes, Ann. N.Y. Acad. Sci., in press.

14 Stell, W.K., Walker, S.E., Chohan, K.S. and Ball, A.K., The goldfish nervus terminalis: A luteinizing hormone-releasing hormone and molluscan cardio-excitatory peptide immunoreactive olfactoretinal pathway, Proc. Natl. Acad. Sci. U.S.A., 81 (1984) 940-944.

15 von Bartheld, C.S. and Meyer, D.L.. Tracing of single fibers of the nervus terminalis in the goldfish brain, Cell Tíssue Res., 245 (1986) 143 158.

16 Walker, S.E. and Stell, W.K., Gonadotropin-releasing hormone (GnRF), molluscan cardioexcitatory peptide (FMRFamide), enkephalin and related neuropeptides affect goldfish retinal ganglion cell activity, Brain Res., 384 (1986) 262273.

17 Zucker. C.L. and Dowling, J.E., Centrifugal fibres synapse on dopaminergic interplexiform cells in the teleost retina, Nature (Lond.). 330 (1987) 166. 168. 